\title{
Mastery of Soft Skills Through Co-curricular Uniform Body
}

\section{Penguasaan Kemahiran Insaniah Melalui Kokurikulum Badan Beruniform}

\author{
Fadillah Ismail $^{*}$ \\ ${ }^{1}$ Fakulti Pengurusan Teknologi dan Perniagaan, \\ Universiti Tun Hussein Onn Malaysia, MALAYSIA \\ *Corresponding Author
}

DOI: https://doi.org/10.30880/jstard.2020.02.03.019

Received 30 September 2020; Accepted 30 November 2020; Available online 31 December 2020

\begin{abstract}
Involvement students in the co-curricular of uniformed bodies is one of the significant alternatives in the effort to apply elements of soft skills among students in IPT. This study is a longitudinal survey study aimed at measuring the level of mastery of soft skills among 912 students who took a uniformed body co-curriculum course. There are seven attributes of insaniah skill (soft skill) for IPT students as outlined by the Ministry of Higher Education Malaysia (KPTM) including communication skills, leadership, teamwork, critical thinking and problem solving, lifelong learning, entrepreneurship and professional moral ethics skills (KPT 2006) applied . Statistical Package for Social Science Version 20 software was used to analyze the findings of this study. The results show that there is a change in the mastery of the mastery of the seven soft skills among students before and after joining the uniformed body.
\end{abstract}

Keywords: Elements of soft skills, higher education, co-curricular, uniform body

\begin{abstract}
Abstrak: Penglibatan dalam kokurikulum badan beruniform merupakan salah satu alternatif yang signifikan dalam usaha menerapkan elemen kemahiran insaniah dalam kalangan mahasiswa di IPT. Kajian ini merupakan kajian tinjauan secara longitudinal bertujuan untuk pengukur tahap penguasaan kemahiran insaniah dalam kalangan 912 pelajar yang mengambil kursus kokurikulum badan beruniform. Terdapat tujuh attribut kemahiran insaniahsoftskill) untuk pelajar IPT seperti yang digariskan oleh Kementerian Pengajian Tinggi Malaysia (KPTM) merangkumi kemahiran komunikasi, kepimpinan, kerja berpasukan, berfikir kritis dan penyelesaian masalah, pembelajaran sepanjang hayat, keusahawanan dan kemahiran etika moral profesional (KPT 2006) digunapakai. Perisian Statistical Package for Social Science Version 20 digunakan untuk menganalisis dapatan kajian ini. Hasil kajian menunjukkan terdapat perubahan peningkataan penguasaan ketujuh-tujuh kemahiran insaniah dalam kalangan mahasiswa sebelum dan selepas menyertai badan berunifrom.
\end{abstract}

Kata Kunci: Kemahiran insaniah, pendidikan tinggi, kokurikulum, badan beruniform

\section{Pengenalan}

Amalan refleksi telah dikenal pasti sebagai bahagian penting dalam pengajaran dan elemen utama untuk pembangunan profesional guru. Ia juga dikatakan untuk merapatkan jurang antara teori dan amalan, mengalihkan 
kebolehan guru kepada penilaian kritikal dan membolehkan guru memainkan peranan yang lebih aktif dalam kebertanggungjawaban mereka sendiri (Shamsiah, 2016). Meningkatkan kemahiran dan amalan refleksi dapat dilihat sebagai cara untuk meningkatkan amalan pengajaran dan hasil refleksi dalam pendidikan guru. Melalaui pelaksanaan 'refleksi' atau penilaian kendiri ke dalam program pendidikan guru, guru pelatih akan berpeluang mempelajari teoriteori baru yang boleh membantu membentuk falsafah pengajaran mereka (Azizi, 2018). Sungguh pun 'refleksi' bukan perkara yang baru di dalam program pendidikan guru namun amalan ini dapat memotivasi guru untuk melaksanakan perubahan positif diri supaya mereka dapat mengajar dengan lebih baik.

Institusi pendidikan guru disarankan untuk menitikberatkan amalan refleksi di kalangan guru pelatih, terutama semasa menjalani latihan praktikum mengajar di sekolah. Dalam Buku Panduan Latihan Praktikum Pengajaran tercatat "guru pelatih dikehendaki menyedia dan menulis serta memberikan laporan refleksi atau penilaian kendiri" selepas tamat menjalani latihan praktikum mengajar mereka. Panduan dan tatacara menulis 'refleksi dan penilaian kendiri' hendaklah disediakan oleh Institut Pendidikan Guru untuk dipatuhi oleh guru pelatih. Ini bermakna guru pelatih dikehendaki untuk mengaplikasikan pemikiran reflektif sebagai satu amalan.

Kajian yang dilaksanakan oleh Bahagian Pendidikan Guru (2014) mendapati bahawa guru pelatih mengakui bahawa mereka masih kekurangan kepakaran dan kemahiran dalam aspek yang melibatkan penulisan dan amalan refleksi. Kajian ini juga mendapati guru pelatih memberikan persepsi yang rendah terhadap aspek bimbingan yang mereka terima daripada pensyarah pembimbing tentang soal-soal yang berkaitan dengan penulisan dan amalan refleksi (Bahagian Pendidikan Guru, 2014).

Selain itu, isu-isu yang ditulis dalam jurnal hanya merupakan perkara-perkara yang biasa dan kurang relevan dengan apa yang dikehendaki dalam sukatan praktikum. Penulisan refleksi dalam kalangan guru pelatih lebih banyak berfokus dalam aspek pedagogi dan masalah murid, sedangkan dalam penulisan refleksi guru pelatih sepatutnya menekankan empat aspek penting iaitu murid, sekolah, pedagogi dan guru pelatih sendiri.

Guru pelatih juga didapati menulis tajuk yang kabur dalam penulisan jurnal praktikum. Keadaan ini membuatkan pensyarah penilai tidak dapat memahami dengan baik apa yang dihuraikan dalam ayat dan perkataan. Penulisan tajuk yang tidak jelas akan membingungkan penilai kerana mereka boleh membuat pelbagai jenis tafsiran. Tajuk juga boleh menggambarkan istilah yang berbeza di dalam sesuatu penulisan refleksi. Oleh itu jika tajuk tidak jelas akan menyebabkan guru pelatih gagal dalam menyampaikan isi penulisan dengan baik.

Oleh itu, refleksi sepertimana yang dinyatakan dalam buku Garis Panduan Latihan Perguruan Praperkhidmatan (Bahagian Pendidikan Guru, 2014) bukanlah satu tugasan atau proses mental yang ringan. Proses refleksi ini dikatakan mempunyai hubungan yang rapat dengan proses-proses inkuiri (Schon, 1982). Sungguhpun amalan refleksi melalui penulisan jurnal bukan merupakan perkara yang mudah, namun begitu kebanyakan guru pelatih masih bersetuju bahawa amalan refleksi melalui penulisan jurnal dapat memabantu mereka dalam meningkatkan keberkesanan PdP dalam bilik darjah (Black, 2001).

Objektif kajian ini adalah untuk; (a) menjelaskan isu-isu yang menjadi fokus penulisan refleksi melalui jurnal praktikum dalam kalangan guru pelatih, (b) menjelaskan pola-pola penulisan isu-isu dalam jurnal praktikum dalam kalangan guru pelatih, dan (c) menganalisis penulisan tajuk jurnal praktikum yang kabur dalam kalangan guru pelatih

\section{Sorotan Karya}

Dewey (1985) menyatakan individu yang mempraktikkan pemikiran refleksi akan sentiasa aktif dalam memikirkan masalah yang dihadapi, komited untuk mencari jalan penyelesaian, sanggup mengorbankan masa bagi memastikan masalah yang dihadapi dapat di atasi dan sentiasa menerima pandangan dari luar yang berpotensi untuk menyelesaikan masalah yang dihadapi. Bagi Boud et al., (1985) refleksi adalah proses meneutralkan kembali segala perasaaan negatif yang menyelubungi pengalaman yang dilalui supaya satu perspektif baru dapat dihasilkan daripada pengalaman tersebut sekali gus berjaya mengubah tingkahlaku dan tindakan seseorang. Ia merupakan tindakan yang bertujuan dan berhati-hati (Loughran, 1996), melakukan penilaian secara kritikal (Mezirow, 1991) dan melibatkan proses menyiasat dan mengenal pasti pengalaman yang telah mereka lalui. Keseluruhannya, pemikiran dan amalan refleksi merupakan suatu aktiviti kognitif yang memerlukan penglibatan aktif individu hasil daripada cetusan sesuatu pengalaman yang amat memberi kesan kepada dirinya dengan melibatkan pengujian tindak balas, kepercayaan dan dasar pemikiran untuk menghasilkan integrasi antara pemahaman baru dengan pengalaman yang telah dilalui. Ia juga sangat perlu diterapkan kepada guru pelatih kerana ia adalah kunci dan elemen yang penting bagi mereka yang baru mula untuk mengenali dunia pengajaran (Giovannelli, 2003).

Amalan refleksi merupakan suatu bentuk pemikiran yang sukar diterjemahkan secara eksplisit. Ong (2004) berpendapat penulisan berupaya memainkan peranan sebagai bahan bukti yang membolehkan guru menterjemahkan pemikirannya secara tersurat untuk diselaraskan dan mengambil tindakan susulan serta salah satu alat yang sangat efektif untuk mengaplikasikan pemikiran dan amalan refleksi adalah jurnal refleksi Melalui penulisan jurnal refleksi individu tersebut dapat menjadi lebih kritikal terhadap pengalaman atau masalah yang dihadapi dan dipertimbangkan segala kemungkinan yang akan berlaku dan berusaha mencari pelbagai alternatif bagi mengatasi situasi tersebut (Hoover, 1994). 


\section{Metodologi}

Kajian berbentuk kualitatif ini dijalankan dengan menggunakan kaedah analisis dokumen. Menurut Cohen et al., (2004) kajian secara kualitatif berupaya mengenal pasti secara terperinci dan lebih mendalam tentang sesuatu keadaan yang dikaji. Kajian dilaksanakan berdasarkan 40 jurnal praktikum yang diakses pada 27 Januari 2020 di laman sesawang MyPOROMS (My Practicum Observation Reports Online Management System). Jurnal yang dianalisis hanyalah berdasarkan jurnal yang ditulis dalam tahun 2019 sahaja. Jumlah jurnal refleksi yang dianalisis adalah sebanyak 40 jurnal yang melibatkan pelbagai opsyen pengajian. Aspek yang dianalisis hanyalah merujuk kepada tajuktajuk penulisan jurnal sahaja dan tidak menganalisis aspek-aspek selain dari pemboleh ubah yang dikaji. Jurnal ini ditulis oleh guru pelatih PISMP semester 7 ambilan Jun 2016 yang telah menjalani latihan mengajar fasa dua di sekolah-sekolah dalam daerah Batu Pahat.

\section{Dapatan dan Perbincangan}

Berikut dikemukakan hasil dapatan kajian ini berdasarkan objektif dan persoalan yang dikemukakan.

\section{Menjelaskan isu-isu yang menjadi fokus penulisan refleksi melalui jurnal praktikum dalam kalangan guru pelatih}

Secara umumnya isu-isu yang menjadi fokus penulisan refleksi melalui jurnal praktikum dalam kalangan guru pelatih terbahagi kepada 3 isu iaitu isu guru pelatih itu sendiri, isu murid dan isu pedagogi. Daripada 40 isu ysng dikemukakan 15 merupakan isu guru pelatih, 18 isu murid dan satu isu pedagogi. Isu yang berkaitan dengan sekolah seperti prasarana, pelaksanaan kurikulum dan kokurikulum tidak disentuh oleh guru pelatih. Terdapat 6 isu yang ditulis oleh pelajar tidak jelas skopnya dan dikategorikan sebagai kabur atau tidak jelas.

Jadual 1- Isu-isu yang menjadi fokus penulisan refleksi melalui jurnal praktikum dalam kalangan pelajar

\begin{tabular}{lcccccc}
\hline Bil & \multicolumn{7}{c}{ Isu } \\
\cline { 2 - 7 } & Guru Pelatih & Murid & Pedagogi & Sekolah & Tidak jelas & Jumlah \\
\hline 1 & 15 & 18 & 1 & Tiada & 6 & 40 \\
\hline
\end{tabular}

\section{Pola Penulisan Isu-Isu Dalam Jurnal Praktikum Guru Pelatih}

Jadual 2 menunjukkan pola-pola penulisan isu-isu dalam jurnal praktikum guru pelatih. Berdasarkan analisis jadual isu-isu yang ditulis guru pelatih dalam jurnal praktikum dibahagikan kepada domain guru pelatih, murid, sekolah dan pedagogi. Hasil kajian didapati guru pelatih banyak mengemukakan isu berkaitan dengan murid berbanding isu guru pelatih dan sekolah. Manakala tiada penulisan jurnal guru pelatih yang berkaitan dengan sekolah. Ini menunjukkan pemilihan isu-isu semasa sesi praktikum dalam kalangan guru pelatih lebih banyak tertumpu dalam aspek tingkah laku murid dan guru pelatih sahaja.

Jadual 2 - Pola penulisan isu-isu dalam jurnal praktikum guru pelatih

\begin{tabular}{|c|c|c|c|c|c|c|c|}
\hline \multirow[t]{2}{*}{ Bil } & \multirow[t]{2}{*}{ Tajuk Jurnal } & \multicolumn{5}{|c|}{ Tema } & \multirow[t]{2}{*}{ Catatan } \\
\hline & & Guru pelatih & Murid & Sekolah & Pedagogi & Tidak Jelas & \\
\hline & & 15 & 16 & 0 & 3 & 6 & 40 \\
\hline 1 & Kawalan Kelas & $\mathrm{X}$ & & & & & SG \\
\hline 2 & $\begin{array}{l}\text { Suai Kenal Antara Guru Dan } \\
\text { Murid }\end{array}$ & $\mathrm{X}$ & & & & & SG \\
\hline 3 & $\begin{array}{l}\text { Kerjasama Yang Kurang Antara } \\
\text { Murid Dalam Kumpulan }\end{array}$ & & $\mathrm{X}$ & & & & Murid \\
\hline 4 & $\begin{array}{l}\text { Masalah Mengingati Nama } \\
\text { Murid }\end{array}$ & $\mathrm{X}$ & & & & & SG \\
\hline 5 & $\begin{array}{l}\text { Masalah Yang Dihadapi Pada } \\
\text { Minggu Pertama }\end{array}$ & & & & & $\mathrm{X}$ & $\begin{array}{l}\text { Tidak } \\
\text { Jelas }\end{array}$ \\
\hline 6 & $\begin{array}{l}\text { Menyesuaikan Diri Dalam } \\
\text { Persekitaran Sekolah }\end{array}$ & $\mathrm{X}$ & & & & & SG \\
\hline 7 & $\begin{array}{l}\text { Sesi Pengenalan Dengan } \\
\text { Sekolah }\end{array}$ & $\mathrm{X}$ & & & & & SG \\
\hline 8 & Murid Enggan Bekerjasama & & $\mathrm{X}$ & & & & Murid \\
\hline 9 & $\begin{array}{l}\text { Stail Pengajaran Dan } \\
\text { Pembelajaran }\end{array}$ & & & & $\mathrm{X}$ & & Pedagogi \\
\hline 10 & Keberkesanan Murid Dalam & & & & & $\mathrm{X}$ & Tidak \\
\hline
\end{tabular}




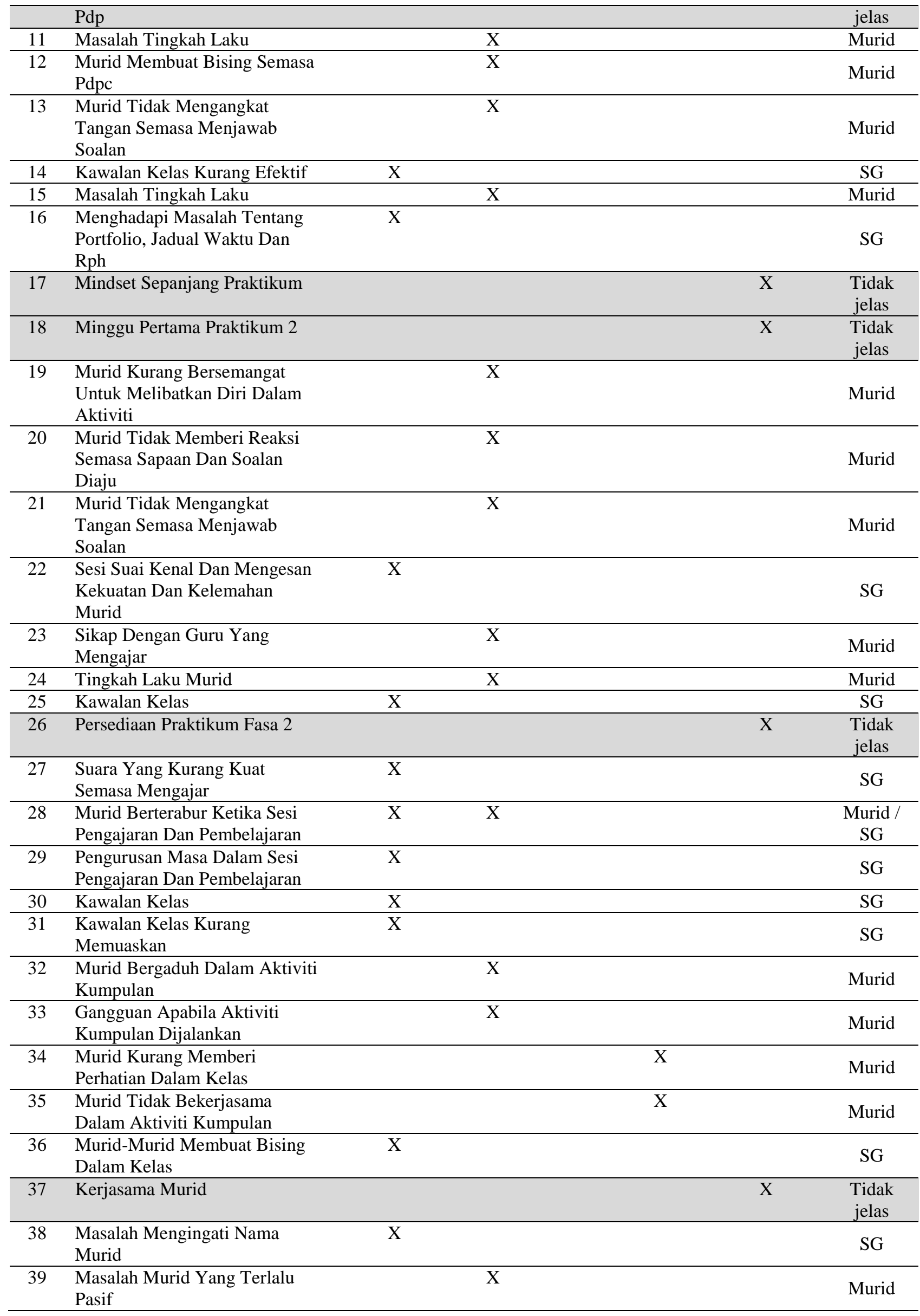




\section{Menganalisis Masalah Penulisan Tajuk Jurnal Praktikum yang Kabur dalam Kalangan Guru Pelatih}

Hanya sebilangan kecil dalam kalangan pelajar yang mempunyai masalah dalam penulisan tajuk jurnal praktikum yang berfokus. iaitu 6 daripada 40 tajuk penulisan jurnal praktikum ditulis tidak jelas. Tajuk-tajuk penulisan jurnal yang dikriteriakan tidak jelas adalah iaalah berikut masalah yang dihadapi pada minggu pertama, keberkesanan murid dalam PdP, mindset sepanjang praktikum, minggu pertama praktikum, persediaan praktikum fasa 2 dan kerjasama murid. Penulisan tajuk yang lain didapati menepati kriteria sama ada berfokus kepada isu pelajar, murid, pedagogi dan sekolah.

\section{Perbincangan}

Berdasarkan kepada dapatan kajian yang diperoleh, guru pelatih di IPGKTHO memfokuskan kepada isu pedagogi, murid, dan guru pelatih sendiri. Kajian ini bersamaan dengan kajian yang dijalankan oleh Larsen, London dan Emke (2016) yang mendapati isu dan masalah yang kerap dicatatkan oleh guru pelatih dalam penulisan jurnal mereka adalah tentang guru pelatih sendiri, pelajar, pengajaran, sekolah, penyeliaan, pembelajaran dan penyediaan. Walau bagaimanapun,dalam kajian ini mendapati isu sekolah tidak disentuh oleh guru pelatih. Perkara ini berlaku disebabkan oleh guru pelatih lebih memfokuskan kepada refleksi kendiri dalam usaha untuk meningkatkan keberkesanan dan kualiti PdP.

Dapatan kajian ini juga selari dengan kajian yang dijalankan oleh Helyer (2015) yang mendapati guru-guru lebih memikirkan tentang isu-isu yang berkaitan dengan masalah pendidikan, kaedah pengajaran, sikap sebagai guru dan pandangan tentang kebolehan dan keadaan pelajar serta menggabungkan isu-isu sosial, etika dan tindakan profesional. Dapatan ini juga telah menyokong kajian dari luar negara, Loughran (2011) dalam penemuan beliau mengenai amalan penulisan jurnal semasa PdP, Loughran (2011) mendapati bahawa guru pelatih menulis tentang isu berkaitan kursus mereka dan pelbagai kebimbangan termasuk diri, pengajaran dan pembelajaran bilik darjah. Tambahan pula, kategori isu dan masalah yang dicatat dalam penulisan jurnal refleksi menunjukkan bahawa guru pelatih hanya mampu menerangkan dan menganalisis perasaan dan kebimbangan peribadi, situasi dan pengalaman serta masalah yang dihadapi semasa praktikum.

Namun, dapatan yang diperoleh penyelididk berlawanan dengan dapatan kajian Yusof (2016) yang mendapati isu-isu yang dikemukakan oleh guru pelatih dalam keadaan semasa (sebenar) merupakan isu-isu yang tidak mengkhusus kepada proses pengajaran dan pembelajaran serta cenderung kepada perkara yang remeh-temeh. Berdasarkan isu-isu yang dicatakan menunjukkan guru pelatih dalam keadaan semasa (sebenar) masih tidak berupaya mencungkil isu-isu yang kritikal berkaitan proses pengajaran dan pembelajaran. Menurut National Science Teacher Association (2013), guru yang berkesan semestinya memberikan tumpuan kepada penguasaan isi kandungan, ciri-ciri pelajar seperti minat, bekerjasama, rasa ingin tahu, berfikiran terbuka, penerapan kemahiran pelajar, cara menangani isu-isu, penguasaan pedagogi, pelaksanaan penilaian yang efektif dan pembangunan keprofesionalan guru.

Dalam aspek penulisan tajuk jurnal yang berfokus didapati pelajar telah dapat menulis tajuk jurnal pratikum dengan baik. ini bersesuaian dengan dapatan kajian Hanipah (2000) yang menyatakan pelajar dapat menulis tajuk yang berfokus kerana telah mendapat bimbingan daripada pensyarah mentor yang dilaksanakan ke atas guru pelatih di institusi masing-masing. Selain pensyarah, guru penyelia dan guru pembimbing di sekolah juga telah memainkan peranan mereka dengan memberi bimbingan dan sokongan, maklum balas ke arah penilaian prestasi pelajar termasuklah dalam aspek penulisan jurnal praktikum. Menurut Chang (2019) pendedahan dalam penulisan refleksi jurnal di institusi masing-masing dapat menjadi panduan untuk melakukan refleksi guru pelatih berjaya mengubah tahap penulisan refleksi mereka ke tahap yang lebih baik meliputi tajuk, isi kandungan dan pemilihan isu yang bersesuaian dengan sekolah mereka ditempatkan.

\section{Kesimpulan}

Guru pelatih yang akan menjalani Latihan Praktikum Mengajar di sekolah sepatutnya dapat mengenal pasti isu dan aspek amalan pengajaran yang diguna di sekolah, menyatakan dan meluahkan perasaan atau suara hati yang terpendam, membentuk dan mengembangkan persepsi kendiri, memperolehi kesedaran baru menyediakan cadangan dan maklumbalas serta merancang pelan tindakan selanjutnya dalam menyelesaikan isu atau aspek berkaitan pendidikan. Penulisan refleksi yang jelas dalam pelbagai aspek dapat membantu guru dalam membuat refleksi pengajaran dan pembelajaran yang bermakna dalam kalangan murid. Adalah penting bagi guru pelatih untuk mengetahui peranan mereka semasa menjalani latihan praktikum mengajar kerana ia adalah komponen penting dalam pendidikan guru, yang menyediakan mereka untuk kerjaya dalam pendidikan. 


\section{Penghargaan}

Penulis ingin mengucapkan terima kasih kepada Institut Pendidikan Guru Kampus Tun Hussein Onn, Batu Pahat, Malaysia atas bantuan dan maklumat yang diberikan untuk memastikan kejayaan kajian ini.

\section{Rujukan}

[1] Bahagian Pendidikan guru. (2014). Garis Panduan Amalan Profesional. PISMP. Putrajaya: Bahagian Pendidikan Guru

[2] Black, S. (2001). Thinking about teaching: How teacher can put reflection at the heart of their teaching. The American School Board Journal, 188, 42-44

[3] Boud, D., Keogh, R., dan Walker, D. (1985). Reflection: Turning experience into learning. London: Kogan Page

[4] Chang, B. (2019). Reflection in learning. Online Learning, 23(1), 95-110. doi:10.24059/olj.v23i1.1447.

[5] Chua Yan, Piaw. (2011). Kaedah Penyelidikan Buku 1. Kuala Lumpur: McGraw Hill

[6] Cohen, L., Manion, L., dan Morrison, K. (2004). Research methods in education. 5th edition. New York: Routledge

[7] Dewey, J. (1985). How We Think. A Restatement Of The Relation Of Reflective Thinking to The educative Process. Boston. D.C. Heath and Company

[8] Giovannelli, M. (2003). Relationship Between Reflective Disposition Toward Teaching and Effective Teaching. The Journal of Educational Research. 5, 293-309

[9] Hanipah Hussin (2000). Daya Berfikir dan Struktur Pemikiran Refleksi Kritikal （Critical Reflection): Bagaimana Amalannya Dalam Pengajaran dan Pembelajaran. Jurnal Teknologi. 31 (E): 31-41

[10] Helyer, R. (2015). Learning through reflection: The critical role of reflection in work-based learning (WBL). Journal of Work-Applied Management, 7(1), 15-27

[11] Hoover, L. (1994). Reflective writing as a window on preservice teachers' thought processes Teaching and Teacher Education. 10(1), 83-93

[12] Kementerian Pendidikan Malaysia (2011). Pelan Pembangunan Malaysia 2013- $\quad 2025 . \quad$ Putrajaya: Bahagian Pendidikan Guru

[13] Larsen, D. P., London, D. A., \& Emke, A. R. (2016). Using reflection to influence practice: Student perceptions of daily reflection in clinical education. Perspectives on Medical Education, 5(5), 285-291. doi:10.1007/s40037016-0293-1

[14] Loughran, J.J. (2011). Effective reflective practice: In search of meaning in learning about teaching. Journal of Teacher Education, 53 (1), 33-43

[15] Loughran, J.J. (1996). Developing Reflective Practice: Learning about teaching and learning through modeling. Washington, DC: Falmer Press

[16] Mezirow, J. (1991). Transformative Dimensions of Adult Learning. San Francisco: JosseBass

[17] National Science Teacher Association. (2013). Standards for science teacher preparation. www.nsta.org/main/pdfs/NSTAstandards2003.

[18] Nor Hasniza Ibrahim dan Muhammad Yusof Arshad. (2005). Keberkesanan Strategi Pelaksanaan Pemikiran dan Amalan Refleksi Dalam Proses Pengajaran dan Pembelajaran Sains Dalam Mempertingkatkan Pemikiran dan Amalan Refleksi Di Kalangan Guru Pelatih Sains Universiti Teknologi Malaysia. Kertas kerja yang dibentangkan dalam Seminar Pendidikan 2005 Pendidikan untuk Pembangunan Lestari pada 28-30 Ogos 2005 di Hotel Shangri-La Pulau Pinang. Anjuran Universiti Sains Malaysia

[19] Nor Hasniza Ibrahim, Johari Surif dan Muhammad Yusof Arshad. (2006). Refleksi: Penilaian Kendiri Guru Yang Berkesan. Kertas kerja yang dibentangkan dalam Kuala Lumpur International Conference on Assessment pada 1619 Mei 2006 di Hotel Sunway Resort. Anjuran Lembaga Peperiksaan Malaysia

[20] Ong, R. (2004). The role of reflection in student learning: a study of its effectiveness in complementing problembased learning environments.

http://discovery.rp.edu.sg/home/ced/research/papers/role_of_reflection_in_student_learning.pdf Di akses pada 15 Februari 2020.Pallant J. (2007). SPSS Survival Manual - A Step by step guide to data analysis using SPSS for Windows. Buckingam: Open University Press

[21] Shamsiah Md Nasir \& Nil Farakh Sulaiman. (2016). Pemikiran Reflektif: Meneroka Amalan Pemikiran Siswa Pendidik.Jurnal Personalia pelajar (18) (2015): 61-68

[22] Schon, D. (1983). The Reflective Practitioner: How professionals think in action. New York: Basic Books.

[23] Yusof, N. (2016). Konsep Pendidikan. Pahang: PTS Professional Publishing Sdn. Bhd 